\title{
Study of the Writing Strategies Used by Chinese Non-English Majors
}

\author{
Yan Chen \\ College English Department, Dezhou University, Dezhou, China \\ Email: chenyancindy@yahoo.com.cn
}

\begin{abstract}
The present study aims to investigate writing strategies used by Chinese non-English majors, the correlation between writing strategies and writing achievements, and the predicative power of writing strategies for writing achievements. The results indicate: (1) Ranked in terms of total frequency, stage strategies used by the subjects are while-writing strategies, pre-writing strategies and revising strategies; (2) Pre-writing strategies and revising strategies positively correlate with students' writing achievements; (3) Writing strategies as a whole have certain predictive power for writing achievements.
\end{abstract}

Index Terms - English writing strategies; English writing achievements; college English writing

\section{INTRODUCTION}

Studies on L2 writing processes could be viewed as a succession of approaches or orientations to L1 writing studies (Silva, 1990). According to Kroll (2003), the notion of writing as a process was introduced to L2 writing studies by Zamel (1976) who argued that advanced L2 writers were similar to Ll writers and could benefit from instructions emphasizing the process of writing. This was confirmed by many later studies committed to the general process of L2 writing.

Zamel (1982) studied eight university-level proficient L2 writers and concluded that L1 process-oriented writing instruction might also be effective for teaching L2 writing, and when students understood and experienced composing as a process, their written product would improve. Zamel's (1983) study of six advanced L2 students further confirmed that L2 writers compose like Ll writers. Cumming (1986, 1987, and 1989) also found that L2 writers were able to rely on their Ll strategies in a series of highly controlled empirical studies on the relationship between writing expertise and L2 proficiency. Hall (1990) revealed striking similarities during the revision process among L2 learners with different backgrounds. Pennington and So's (1993) comparison of both the processes and products across Ll and L2 writing of six Singaporean university students proved that their writing processes were not linear, involving a constant interplay of thinking, writing, and revising throughout the whole process.

Studies and teaching of L2 writing, mainly of English writing, in China began in the early 1990s, much later than those in the western countries. The following are some of meaningful findings on writing strategies in China. Yang' (2002) study is one of the few attempts undertaken in China to explore students' strategy use during their writing process. Using questionnaire design and think-aloud composing as the source of data, Yang found that successful writers differed from unsuccessful ones in planning, focusing and revising. Deng et al (2003), from a theoretical perspective of view, also called for the need to introduce writing strategies into English writing classes. Wang (2007) describes and evaluates studies on the general pattern of the L2 writing process, the relationship among linguistic proficiency, writing ability and L2 writing, the comparison of writing processes in L1 and in L2, the use of the mother tongue and translation in the L2 writing process, learning strategies and the L2 writing process, and writing processes of Chinese ESL/EFL learners.

However, as far as the relationship between the use of learning strategies and students' learning outcomes is concerned, there seems to be inadequate evidence. As for the specific field of writing, Yang (2002) discovered in her correlation study that among all the 27 independent variables examined, only 4 items reached statistical significance. What is more, all these 4 items belonged to the same writing strategy: revising. Apart from Yang's (2002) study, very few empirical studies can be found as to how the use of writing strategies correlates with students' writing achievement. This research is intended to focus on the correlations between the writing strategies and writing achievements.

This study is initiated by the poor writing performances of the college students the author is teaching. It is aimed at investigating the English writing strategies that Chinese non-English majors employ and analyzing the correlations between their English writing strategies and writing achievements. It is also aimed at investigating whether certain writing strategies can predict writing achievements.

\section{THEORETICAL BACKGROUND}

In the current study, Petric and Czarl's writing strategy questionnaire is adapted to investigate the writing strategies used by non-English majors. Besides, Oxford's framework of language learning strategies and the process theory are 
used to analyze and discuss the findings of the investigation.

According to the three writing stages identified by the process theory of writing, the writing strategies in the questionnaire can first be classified into three types of stage strategies: pre-writing strategies, while-writing strategies and revising strategies. Then, the author introduces Oxford's six groups of strategies and further classifies the stage strategies into strategy groups, that is, the pre-writing strategies include the metacognitive and cognitive strategy groups; the while-writing strategies include the metacognitive, cognitive, memory, social and compensation strategy groups; the revising strategies include the metacognitive, cognitive, memory, social and affective strategy groups. In addition, in order to get a more detailed understanding of the strategies use in the process of writing, the author adopts Oxford's classification of strategy groups into individual strategies.

In this study, the following three specific questions are to be answered:

- What strategies are the most frequently employed by non-English majors in English writing?

- What are the correlations between writing strategies use and writing achievements of the students?

- Can the use of certain writing strategies predict writing achievements? If it can, how does it predict?

\section{Methodology}

\section{A. Subjects}

The subjects involved in the study were 132 college students at Dezhou University. They were in the first term of their second year college study, majoring in mathematics education, pre-school education and modern textile technology. With six years' English learning experience at middle school and a year and a half college study, these subjects have generally developed relatively stable learning behaviors. The sample was narrowed down to 116 after the investigation through questionnaires, because some students did not answer their questionnaires properly: Some just left out one or more items of the questionnaire and some chose more than one answer to an item.

\section{B. Instruments}

The instruments used in the present study include a writing test, a writing strategy questionnaire and an interview.

A writing test to be conducted in class was designed to measure writing achievements. In the writing test, all the subjects are required to write a composition of about 150 words on the topic "Positive and Negative effects of the Internet". The internet, which is familiar to the students, was chosen as the topic in order that the writing task would not be too difficult for the students, and that they would have some ideas to write. The students' compositions would be scored according to their content and language respectively.

The data for this study were collected through a writing strategy questionnaire based on Petric and Czarl's writing strategy questionnaire in their published article "Validating a Writing Strategy Questionnaire" (Petric \& Czarl, 2003). In the conclusion of that article, the authors made some suggestions for modifications of the questionnaire so that it would suit investigations into writing strategies in further research. At Petric and Czarl' suggestions, the author of the current study made a few minor changes to the questionnaire. Then the questionnaire was translated into Chinese, tested in a pilot study and finally administered to collect information on language learners' writing strategies and individual background in the current study.

TABLE I

A DESCRIPTION OF THE WRITING STRATEGIES

\begin{tabular}{|c|c|c|}
\hline Stage strategy & Strategy group & Individual strategy \\
\hline \multirow[t]{2}{*}{ Pre-writing Strategies } & Metacognitive & $\begin{array}{l}\text { Planning } \\
\text { Identifying } \\
\text { Overviewing } \\
\text { Organizing }\end{array}$ \\
\hline & Cognitive & $\begin{array}{l}\text { Resourcing } \\
\text { Translating }\end{array}$ \\
\hline \multirow{5}{*}{ While-writing strategies } & Metacognitive & $\begin{array}{l}\text { Goal-setting } \\
\text { Self-monitoring } \\
\text { Organizing } \\
\text { Overviewing } \\
\end{array}$ \\
\hline & Cognitive & $\begin{array}{l}\text { Repeating } \\
\text { Recognizing } \\
\text { Translating } \\
\text { Resourcing } \\
\end{array}$ \\
\hline & Memory & New-word \\
\hline & Social & Peer-cooperating \\
\hline & Compensation & $\begin{array}{l}\text { Approximating } \\
\text { Synonym }\end{array}$ \\
\hline \multirow{5}{*}{ Revising strategies } & Metacognitive & $\begin{array}{l}\text { Goal-setting } \\
\text { Self-monitoring } \\
\text { Paying attention } \\
\text { Identifying } \\
\end{array}$ \\
\hline & Cognitive & $\begin{array}{l}\text { Resourcing } \\
\text { Repeating }\end{array}$ \\
\hline & Memory & Keywords \\
\hline & Social & $\begin{array}{l}\text { Teacher-cooperating } \\
\text { Peer-cooperating }\end{array}$ \\
\hline & Affective & Self-rewarding \\
\hline
\end{tabular}


The final version of the questionnaire, which was used as the instrument of this study, has two sections. The first section aims to investigate students' background information. It contains three blanks, four multiple-choice questions and two open-ended questions. The second section is to explore information about students' writing strategy use during their writing processes. It contains a list of written statements, each of which presents an assertion about the use of a writing strategy. The format is in accordance with Oxford's SILL, which uses a five-point Likert scale ranging from 1 (never or almost never true of me) to 5 (always or almost always true of me). Students are asked to indicate the frequency with which they use a strategy implied in the statement by circling the number which represents their response. The higher number indicates a more frequent use of the strategy concerned. The items are sequenced following the structure of the writing process, i.e. pre-writing, writing, and revising stages, so as to provide a clear frame of reference to the students. Altogether, there are 3 stage strategies, 12 strategy groups, and 28 individual strategies involved in the questionnaire. Table 1 gives a description of the strategies.

One point needs to be noted here, that is, in order to get a clear picture of what strategies students employ in each writing stage, a strategy group with the same name in different stages is viewed as different strategy groups. For example, since the metacognitive strategy group is involved in all the three stages, it is viewed as three separate strategy groups: metacognitive strategy group in the pre-writing stage, metacognitive strategy group in the while-writing stage, and metacognitive strategy group in the revising stage. This is also true with the individual strategies. For instance, there is the organizing strategy in the pre-writing stage and the organizing strategy in the while-writing stage respectively. The whole questionnaire is compiled in Chinese for the sake of clear understanding and accurate response.

With the conviction that a single method would not produce adequate information about the subjects, an interview with some of the students was conducted to gather supporting information for the study. Ten students, five males and five females, were randomly selected and interviewed one after another by the author two days after colleting the composition. In the interview there are specific core questions determined in advance from which the author could branch off to explore in-depth information. The questions are as follows:

- Do you like English writing? Why?

- Do you often write in English?

- How do you usually begin to write on a topic and go on with it?

- What do you think is the most difficult problem with writing in English?

- How are you taught to write in English?

All the students responded the questions in a friendly way. According to the way the interview carried out, some more questions, mainly about the process of writing, were asked, and in order not to interrupt the talks, the answers were noted down in retrospect by the author during the intervals. All in all, it took nearly three hours to undertake the task of the interviews.

\section{Pilot Study}

A pilot study was conducted in September 2008, two weeks before the real data collection procedures, in order to revise the questionnaire, check testing procedures, determine the anticipated length of time needed for administering the survey, and check the reliability of the questionnaire. In the pilot study, the questionnaire was tested with 36 students from Dezhou College. Before the questionnaires were distributed, subjects were instructed that they only had to rank the choices with numbers from one to five or circle one of the five numbers to indicate their true opinions.

The internal reliability of the questionnaire was calculated by computing its Cronbach alpha to examine the consistency of the research. As the questionnaire covers three different stages: pre-writing strategies, while-writing strategies and revising strategies, their reliability was calculated separately as presented in table 2.

TABLE 2

RELIABILITY ANALYSIS

\begin{tabular}{|lccc|}
\hline Reliability coefficients & \multicolumn{3}{l|}{} \\
\hline Pre-writing strategies & No. of cases $=36$ & No. of items $=7$ & Alpha $=.84$ \\
\hline While-writing strategies & No. of cases $=36$ & No. of items $=13$ & Alpha $=.89$ \\
\hline Revising strategies & No. of cases $=36$ & No. of items $=15$ & Alpha $=.93$ \\
\hline
\end{tabular}

The reliability of an instrument concerns whether this instrument will produce the same results each time it is administered to the same person in the same setting (George \& Mallery, 2000). Coefficient alpha is one of the ways to measure reliability. According to the pilot study, the internal consistency reliability for prewriting strategies is .84 , that for the while-writing strategies is .89 , and that for the revising strategies is .93 , which is acceptable.

\section{Data Collection Procedures}

One point is worth mentioning for the procedures of data collection, that is, the writing test was conducted before the filling out of the questionnaire, because it was feared that the questionnaire could to some extent remind the students of the use of some writing strategies and thus influence the validity of the investigation.

A week before filling out the questionnaire, the subjects were requested to write a composition of about 150 words on the topic "Positive and Negative Effects of the Internet" after class. The 132 college students' composition' were collected before filling out the questionnaire. Among the 132 compositions, 16 were picked out because later on the 
writers did not answer the questionnaire properly. As a result, there were 116 compositions to be scored.

When scoring the students' compositions, one common practice in the field of L2 writing research is to use two or more teachers. In the current study, two people participated in grading the compositions. The first is the author of the study; another is an experienced teacher who teaches college English writing for a considerable number of years. The content and language of a composition were scored respectively, and then their mean was calculated out as the overall scores of the composition. Both the full language score and content score of a composition were set at 100 . The overall composition scores, which are referred to as a student's writing achievements in this study, are the mean of its language scores and content scores. Thus the overall scores of a composition are also 100. An example as follows may make this calculation clearer: if a student's language scores and content scores are 70 and 60 respectively, his overall composition scores, or his writing achievements, will be the mean of 70 and 60, i.e., 65 .

Referring to the CET-4 writing assessment standards, the evaluators worked out their own standards for evaluating students' writing. In addition, before the actual scoring of the subjects' compositions, the evaluators did some training: two compositions were randomly selected from those which were collected during the pilot study of the writing test, and scored according to the standards that were made; then the scores given by the two evaluators were compared and manipulation of the standards were discussed and agreed on. The two evaluators scored the compositions separately without consulting with one another.

Each subject's composition was typed as it is into a computer and printed in two copies. The texts that the evaluators scored and the texts that the students had written were the same except that the former are typed whereas the latter are hand-written. The compositions that the students turned in were not evaluated directly because the author is afraid that students' handwriting would influence their composition scores. In a similar study by Wang and Wen (2002), the students' handwriting was not considered too, and they also had the students' writing typed. Since their study was reported and published in a major journal, it can be assumed that their techniques in evaluation of the compositions are acceptable. It would be safe for this study to adopt some of those techniques.

One point was emphasized to the student before the subjects fill out the questionnaire, that is, they should be serious and honest in answering the questionnaire. Since it was the first time that the subjects had come across a questionnaire like this, after the questionnaires were distributed to the students, instructions were made as for how to answer the questionnaire. The teacher read aloud to the students the explanations at the beginning of the second section, and instructed them how to make a choice by explaining with the example provided in the questionnaire. Finally, the teacher emphasized to the students that they should not forget to answer any item. Then they were allowed to fill in the questionnaires and encouraged to ask the teacher whenever they had any question. It took about 20 minutes for the students to finish the questionnaire and meantime the students raised no question about any statement of the questionnaire. Altogether 132 questionnaires were collected, but 16 of them were picked out because the 16 students just left out some blanks or items, though the teacher had reminded them not to.

The collected data through the questionnaire are for the independent variables: 3 stage strategies, 12 strategy groups and 28 individual strategies. Since the reliability of the questionnaire has already been explained, the reliability of each independent variable is not presented here.

All the data collected through the compositions and questionnaires were put into a computer and analyzed through SPSS. Descriptive statistics, including frequencies, means and standard deviations, were calculated to show the students' use of writing strategies. Correlation analyses were conducted to demonstrate the correlations between the independent variable, i.e., the writing strategies use (operationalized in this study as strategy items in questionnaire) and the dependant variable, i.e., writing achievements (operationalized as the scores that students obtained in the writing test). Multiple regression analyses were conducted to measure the predictive power of strategies for students' writing achievements.

\section{RESUlT AND DisCUSSION}

\section{A. Writing Strategies Commonly Used by the Students}

As can be seen from Table 3, although Chinese non-English majors do use some kinds of strategies in the pre-writing stage, while-writing stage and revising stage, they are still not frequent users of many of them. The result of the descriptive statistics on the three types of stage strategies can be interpreted in this way: in the while-writing stage, the students employ writing strategies more often than in the prewriting or revising stage. This result could be attributed to the product approach to writing teaching, in which most of the subjects have been taught. 
TABLE 3

\begin{tabular}{|c|c|c|}
\hline $\begin{array}{l}\text { Stage strategy } \\
(\mathrm{M}, \mathrm{SD})\end{array}$ & $\begin{array}{l}\text { Strategy group } \\
(\mathrm{M}, \mathrm{SD})\end{array}$ & $\begin{array}{l}\text { Individual strategy } \\
(\mathrm{M}, \mathrm{SD})\end{array}$ \\
\hline \multirow[t]{2}{*}{$\begin{array}{l}\text { Pre-writing } \\
\text { Strategies } \\
(2.85, \quad 54)\end{array}$} & $\begin{array}{l}\text { Metacognitive } \\
(3.21, .75)\end{array}$ & $\begin{array}{l}\text { Planning }(2.65, .84) \\
\text { Identifying }(4.04, .74) \\
\text { Overviewing }(2.53, .97) \\
\text { Organizing }(3.20,1.14) \\
\end{array}$ \\
\hline & $\begin{array}{l}\text { Cognitive } \\
(2.59, .78)\end{array}$ & $\begin{array}{l}\text { Resourcing }(2.40,1.03) \\
\text { Translating }(2.78,1.16) \\
\end{array}$ \\
\hline \multirow{5}{*}{$\begin{array}{l}\text { While-writing } \\
\text { Strategies } \\
(3.04, .43)\end{array}$} & $\begin{array}{l}\text { Metacognitive } \\
(2.99, .61)\end{array}$ & $\begin{array}{l}\text { Goal-setting }(3.16, .91) \\
\text { Self-monitoring }(2.98,1.03) \\
\text { Organizing }(3.47, .91) \\
\text { Overviewing }(2.35, .91)\end{array}$ \\
\hline & $\begin{array}{l}\text { Cognitive } \\
(2.97, .52)\end{array}$ & $\begin{array}{l}\text { Repeating }(2.54,1.02) \\
\text { Recognizing }(3.84, .83) \\
\text { Translating }(2.98, .84) \\
\text { Resourcing }(2.52, .95)\end{array}$ \\
\hline & Memory $(2.14, .84)$ & New-word $(2.14, .84)$ \\
\hline & Social $(3.14, .90)$ & Peer-cooperating $(3.14, .90)$ \\
\hline & $\begin{array}{l}\text { Compensation } \\
(3.95, .59) \\
\end{array}$ & $\begin{array}{l}\text { Approximating }(3.89, .79) \\
\text { Synonym }(4.01, .61)\end{array}$ \\
\hline \multirow{5}{*}{$\begin{array}{l}\text { Revising } \\
\text { Strategies } \\
(2.56, .45)\end{array}$} & $\begin{array}{l}\text { Metacognitive } \\
(2.87, .48)\end{array}$ & $\begin{array}{l}\text { Goal-setting }(2.89, .98) \\
\text { Self-monitoring }(2.64, .59) \\
\text { Paying attention }(2.51, .91) \\
\text { Identifying }(3.41, .85) \\
\end{array}$ \\
\hline & $\begin{array}{l}\text { Cognitive } \\
(2.32, .68) \\
\end{array}$ & $\begin{array}{l}\text { Resourcing }(2.56, .97) \\
\text { Repeating }(2.08, .74) \\
\end{array}$ \\
\hline & Memory $(1.80, .68)$ & Keywords $(1.80, .68)$ \\
\hline & Social $(3.19, .76)$ & $\begin{array}{l}\text { Teacher-cooperating }(3.74, .90) \\
\text { Peer-cooperating }(2.63, .91)\end{array}$ \\
\hline & Affective $(2.61,1.06)$ & Self-rewarding $(2.61,1.06)$ \\
\hline
\end{tabular}

As far as the individual strategy is concerned, the compensation strategies (mean=3.95) is used with the highest frequencies. It reveals that EFL learners do frequently employ various strategies to overcome problems or difficulties encountered in the process of writing. The result is consistent with Jiang Xiaohong's (2003) finding. Compensation strategies, as discussed in Oxford (1990, p.47), enable learners to use the new language for either comprehension or production despite limitations in knowledge. These are intended to make up for an inadequate repertoire of grammar and, especially, of vocabulary. Researchers have always paid attention to compensation strategies for speaking, such as using mime or gesture. However, other compensation strategies like adjusting or approximating the message, using a circumlocution or synonym can also be used in writing as well as in speaking. As far as the individual strategy is concerned, the memory strategy is used with the lowest frequencies. The memory strategy group in the while-writing stage is embodied by the new-word strategy, or the strategy of placing new words into a context. The aim of investigating this strategy is to know whether or not a student is accustomed to reading only the English explanations of a new word while using their dictionaries. It turns out that the mean of this strategy is 2.14 , which suggests that 'to read only the English explanations" is close to "usually not true" of the students. This finding is exactly consistent with what Oxford (1990, p.40) has brought forward: "although memory strategies can be powerful contributors to language learning, language students rarely report using these strategies either because they do not use memory strategies very much or because they are unaware of how often they actually do employ memory strategies". As is known, the English words used to explain or define in a dictionary are usually simple ones; the students should have already learned most of them in their secondary schools. Nevertheless, they still do not get used to learning the usage of a word only in its English context. It is assumed that two possibilities may account for this phenomenon: on the one hand, the students do not learn their English well in the secondary schools and still have difficulties in understanding the English explanations; on the other hand, they can understand the English explanations well enough, but just do not get used to the way of only reading the English explanations.

\section{B. Correlations between Stage Strategies Use and Writing Achievements}

Pre-writing strategies and revising strategies positively correlate with students' writing achievements indicates that the more often students use the strategies, the higher scores they would get in the writing test. Further correlation analyses between pre-writing and revising strategies use and content and language scores show that the use of pre-writing and revising strategies positively correlates with content scores and language scores respectively, in other words, the more often students use strategies, the more content scores and language scores they will get. The results are showed in Table 4. 
TABLE 4

THE CORRELATIONS BETWEEN STAGE STRATEGIES AND WRITING ACHIEVEMENTS, CONTENT SCORES AS WELLAS LANGUAGE SCORES

\begin{tabular}{|lllll|}
\hline & & $\begin{array}{l}\text { Pre-writing } \\
\text { strategies }\end{array}$ & $\begin{array}{l}\text { While-writing } \\
\text { strategies }\end{array}$ & Revising strategies \\
achiting & Pearson Correlation & $.254(* *)$ & .146 & $.397(* *)$ \\
Content & Sig. (2-tailed) & .006 & .119 & .000 \\
& Pearson Correlation & $.275(* *)$ & .129 & $.360(* *)$ \\
& Sig. (2-tailed) & .003 & .169 & .000 \\
Language & Pearson Correlation & $.203(*)$ & .142 & $.381(* *)$ \\
& Sig. (2-tailed) & .028 & .128 & .000 \\
& $\mathrm{~N}$ & 116 & 116 & 116 \\
\hline
\end{tabular}

** Correlation is significant at the 0.01 level (2-tailed).

* Correlation is significant at the 0.05 level (2-tailed).

\section{The Predictive Power of the Writing Strategies}

The multiple regression analyses imply that the writing strategies as a whole have significant predictive power not only for the writing achievements, but also for content scores and language scores.

From table 5 , it can be seen that the writing strategies as a whole predict $16.4 \%$ of the variance in students' writing achievements, the writing strategies as a whole predict $15.6 \%$ of the variance in students' content scores, and the writing strategies as a whole predict $13.2 \%$ of the variance in students' language scores. From this, it can be concluded that the writing strategies as a whole only have certain predictive power for the writing achievements, content scores and language scores. The result further confirms the finding about learner factors in language learning, that is, besides writing strategies, there are many other factors that may contribute to the development of students' writing ability. To name a few of them, situational factors such as language learning setting, task demands, and various individual learner differences such as learning beliefs, L2 proficiency, L1 writing ability, learning style, personality, and motivation all may have direct or indirect influence on students' writing achievements. Therefore, strategy has certain predictive power for writing achievements, but it is not the only factor.

TABLE 5

THE MULTIPLE REGRESSIONS BETWEEN WRITING STRATEGIES AND WRITING ACHIEVEMENTS, CONTENT SCORES AND LANGUAGE SCORES

\begin{tabular}{|l|l|l|l|l|}
\hline Lependent variable & Multiple R & R Square & F & P \\
\hline Writing Achievements & .405 & .164 & 22.36 & .000 \\
\hline Content Scores & .395 & .156 & 21.071 & .000 \\
\hline Language Scores & .363 & .132 & 17.337 & .000 \\
\hline
\end{tabular}

In order to have a clearer idea about the relationship between various factors and English writing outcomes, a model (see Fig. 1)was designed which was adapted from Ellis (1994, p.473-530).

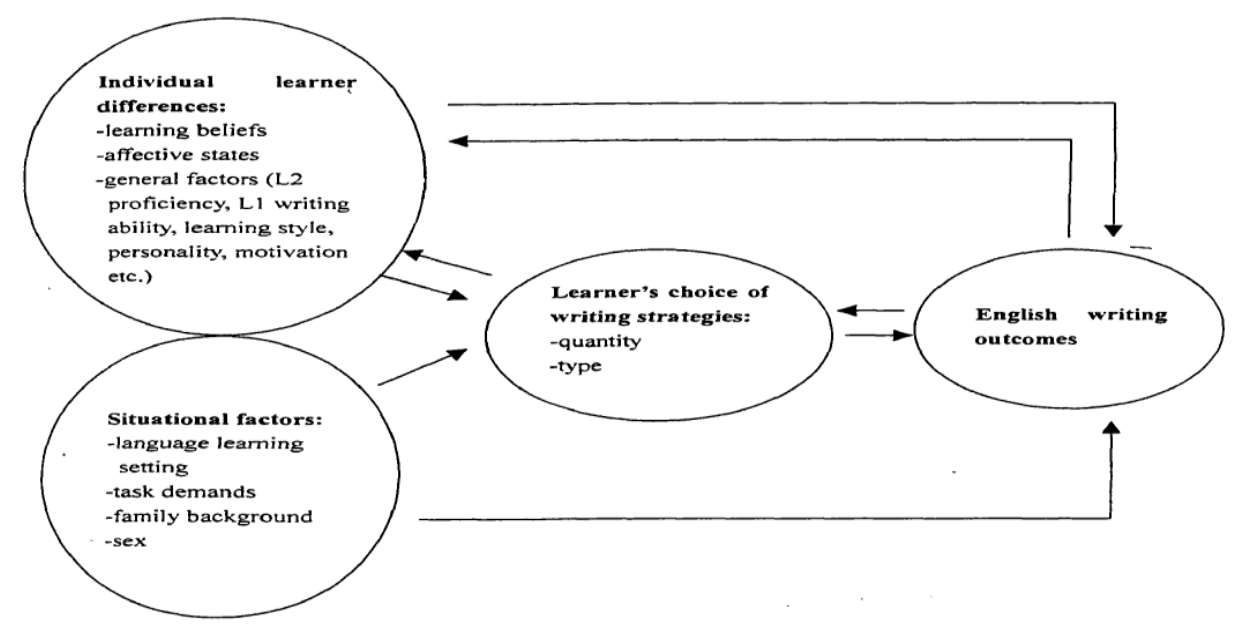

Figure 1: The relationship between various factors and English writing outcomes 


\section{CONCLUSIONS}

The findings in this study provide much insight into English writing teaching. Firstly, although students can frequently make use of some strategies, such as identifying strategies and compensation strategies, other strategies are receiving relatively insufficient attention. So teachers can spend some time introducing these strategies to make students to be aware of all the writing strategies available scores. Secondly, from the descriptive analysis of the three types of stage strategies, it can be seen that the revising stages are to some extent neglected; therefore, the teachers should introduce the process approach to the English writing teaching.

Although this study can shed some light on the teaching of writing for Chinese non-English majors, it has some limitations, however. First, the subjects in the present study come from the same college, and the sample is not so big. So the conclusion may not be generalized on a large scale. In addition, the classification of the questionnaire items into individual learning strategies as defined by Oxford is somewhat subjective. Therefore, further studies should be carried out to complement the results of the present study in order to confirm the effectiveness of the process approach and writing strategies to the teaching of college English writing.

\section{REFERENCES}

[1] Cumming, A. (1986). Intentional Learning as a principle for ESL Writing Instruction: A Case Study. TESL Canadian Journal (special issue), 1, 69-83.

[2] Cumming, A. (1987). Decision making and text representation in ESL writing performance. Paper Presented at the 21st Annual TESOL Convention, Miami, April.

[3] Cumming, A. (1989). Writing expertise and second language proficiency. Language learning, 39(1), 81-141.

[4] Deng, Liming et al. (2003). A Systematic Study of Process Approach and Its Implications for the Teaching Reforms of College English Writing. Foreign language Education, 6: 58-62.

[5] Ellis, R. (1994). The Study of Second Language Acquisition. Oxford: Oxford University Press.

[6] George, D \& P. Mallery. (2000). SPSS for Windows: Step by Step. Needham Heights, MA: A Pearson Education Company.

[7] Hall. (1990). Managing the complexity of revising across languages. TESOL Quarterly 24(1): 43-60.

[8] Jiang, Xiaohong. (2003). The Influence of Achievement Motivation and Attributional Beliefs on EFL Learning Strategy Use. Journal of Pla University of Foreign Languages, 2: 69-72.

[9] Kroll, B. (2003). Introduction: Teaching the next generation of second language writers. In Kroll, B (ed.), Exploring the Dynamics of Second Language Writing (1-10). Cambridge: Cambridge University Press.

[10] Oxford, R. L. (1990). Language Learning Strategies: What Every Teacher Should Know. New York: Newbury House.

[11] Pennington, M. C. \& So, S. (1993). Comparing Writing Processes and Product across Two Languages: A Study of 6 Singaporean University Student Writers. Journal of Second Language Writing, 2(1), 41-63.

[12] Petric, B. \& Czarl, B. (2003). Validating a Writing Strategy Questionnaire. System, 31: 187-215.

[13] Silva, T. (1990). Second language composition instruction: Developments, issues, and directions in ESL. In Kroll, B. (ed.), Second Language Writing. Cambridge: Cambridge University Press.

[14] Wang, Junju. (2007). Review of studies on L2 writing processes: cognitive and psychological perspectives, Foreign language World, 5: 2-9.

[15] Wang, Wenyu. \& Wen, Qiufang. (2002). The Influence of L1 Thinking on L2 Writing. Foreign Languages and Their Teaching, 10:18.

[16] Yang, Shuxian. (2002). The Differences of Using Strategies between Successful Writers and Unsuccessful Writers. Foreign Language World, 3: 57-64.

[17] Zamel, V. (1976). The Composing Process of Advanced ESL Classroom: What Can We Learn From Research in the Teaching of English? TESOL Quarterly 10(2), 67-76.

[18] Zamel, V. (1982). Writing: The Process of Discovering Meaning. TESOL Quarterly 16 (2), 195-209.

[19] Zamel, V. (1983). The Composing Processes of Advanced ESL Students: Six Case Studies. TESOL Quarterly 17(2), 165-187.

Yan Chen was born in Yucheng, China in 1979. She received her M.A. degree in linguistics from Shandong University, China in 2009.

She is currently a lecturer in the Department of College English Teaching, Dezhou University, Dezhou, China. Her research interests include linguistics and applied linguistics.

Ms. Chen won the third prize in the Second Powerpoint Design of English Classroom Teaching for Vocational College Students of Shandong Province. 